\title{
Clinical Indicators of Surgical Thyroidectomy in Graves' Disease
}

\section{PRK Bhargav}

\section{ABSTRACT}

Pathognomonic clinical triad of Graves' disease are diffusely enlarged goiter, exophthalmos, and acropachy. Thyroidectomy appears to be ideal treatment for this condition in comparison to radioiodine.

Keywords: Goiter, Radioiodine therapy, Thyroidectomy.

How to cite this article: Bhargav PRK. Clinical Indicators of Surgical Thyroidectomy in Graves' Disease. World J Endoc Surg 2016;8(3):220.

\section{Source of support: Nil}

\section{Conflict of interest: None}

\section{INTRODUCTION}

The clinical image shows bilateral exophthalmos, large diffuse goiter, and clubbing of fingers in a 45-year-old gentleman with clinical features of hyperthyroidism. The triad is strongly suggestive of Graves' disease or toxic diffuse goiter. Especially, thyroid acropachy characterized by clubbing of fingers and toes is a characteristic stigmata of this condition. ${ }^{1}$ Graves' disease is an organ-specific autoimmune thyroid disease caused by thyrotropin (TSH) receptor stimulating antibodies. ${ }^{2}$ Amongst the three therapeutic options, surgical thyroidectomy appears to

Consultant and Ex-Associate Professor

Department of Endocrine and Metabolic Surgery, Endocare Hospital, Vijayawada, Andhra Pradesh, India

Corresponding Author: PRK Bhargav, Consultant and ExAssociate Professor, Department of Endocrine and Metabolic Surgery, Endocare Hospital, Vijayawada, Andhra Pradesh, India Phone: +918666617633, e-mail: kingbhargav@gmail.com

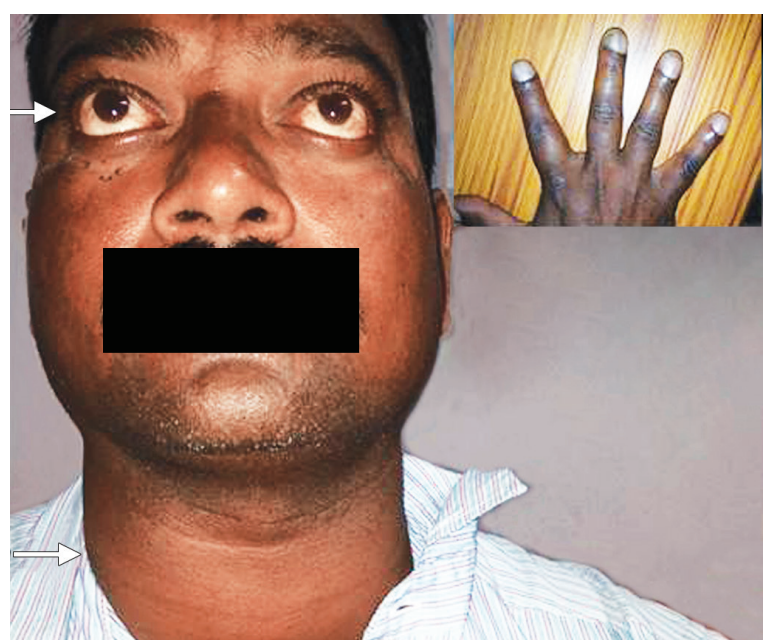

Fig. 1: Bilateral exophthalmos, diffuse goiter, and acropachy (inset showing digital clubbing)

be optimal compared to antithyroid drugs or radioiodine for permanent resolution of disease. ${ }^{3}$ Twelve months after uneventful total thyroidectomy and thyroxine replacement, the patient had significant relief of symptoms and resolution of all clinical stigmata (Fig. 1).

\section{REFERENCES}

1. Fatourechi V, Ahmed DD, Schwartz KM. Thyroid acropachy: report of 40 patients treated at a single institution in a 26-year period. J Clin Endocrinol Metab 2002 Dec;87(12):5435-5441.

2. Rees Smith B, MacLachlan SM, Furmaniak J. Autoantibodies to the thyrotropin receptor. Endocr Rev 1988 Feb;9(1): 106-121.

3. Frilling A, Goretzki PE, Grussendorf M, Erbsloh M, Roher HD. The influence of surgery on endocrine ophthalmopathy. World J Surg 1990 May-Jun;14(3):442-446. 